\title{
MULTI-CRITERIA ANALYSIS OF AGRICULTURE IN A RURAL SPACE. CASE STUDY: ARGEȘ COUNTY
}

\author{
George SECĂREANU* \\ Interdisciplinary Center for Advanced Research on Territorial Dynamics (CICADIT), \\ Faculty of Geography, University of Bucharest, Romania, \\ e-mail: secareanugeorge@yahoo.com \\ Irina FLOREA-SAGHIN \\ Faculty of Natural and Agricultural Sciences, Ovidius University of Constanța, Romania, \\ e-mail: $\underline{\text { rinasaghin@gmail.com }}$

\section{Igor SÎRODOEV} \\ Faculty of Natural and Agricultural Sciences, Ovidius University of Constanța, Romania, \\ e-mail: ingvarri@gmail.com.
}

Citation: Săcăreanu G., Floarea-Saghin I., Sîrodoev I. (2019). Multi-Criteria Analysis of Agriculture in a Rural Space. Case Study: Argeș County. Analele Universităţii din Oradea, Seria Geografie, 29(1), 69-78. https://doi.org/10.30892/auog.291108-800

\begin{abstract}
This analysis has the intention to highlight the territorial differentiation of the agricultural development's vulnerabilities in the agricultural areas from Argeș County. Thereby a determinant and eliminatory factor in agriculture is given by the average slopes greater than $20 \%$ and altitudes greater than $700 \mathrm{~m}$. By consequences, 16 villages have been excluded. The study has emphasized an increasing of territorial vulnerabilities, which tend to intensify in the rural areas. The analysis of the agricultural development's growth is based on four main criteria: the use of agricultural land; the fragmentation of agricultural land; the viability of agricultural companies and the types of agricultural exploitation. Therefore, through the variety of the indicators that have been used, the analysis offers an image of the spatial layout of the agricultural development in the 95 settlements under discussion. Moreover, the degree of development for an industrial branch is observed through this problem, so common in the emerging economies.
\end{abstract}

Key words: Argeș County, the Hull indicator, agricultural development, rural areas

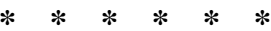

\section{INTRODUCTION}

This paper aims to identify the development of agriculture in Argeș County, these being represented bydifferent stages of agricultural development which can affect primarily the 
population through its actions and through the external factors, thus limiting the ways of life and also the connections between these communities as a whole economic group (Bose, 2015; Filimon et al., 2014). Such a context represents the main concern for the humanistic geographers concerning the rural areas which have their main activities in the primary sector.

The poor agricultural development represents a major problem in our society. Agriculture itself has many subtle and hard to quantify characteristics, thus being difficult to extrapolate eventual unscheduled phenomena that are dependent on the existing reality. This study has into consideration offering a stringent approach of the agricultural development in the rural areas from Argeș County. Another aspect here under discussion is based on the agricultural use itself and on its dynamic in the local economy, in the county's economy, in the national and even in the global economy (Bunnell and Coe, 2001).

Based on this context, different areas without an agricultural singularity and with an economy focused on other economic sectors as having a poor agricultural development. However, these aspects need to be observed from a practical point of view and when the land characteristics require such a comparison, it is necessary that this could be achieved and also to it has to reflect possible discrepancies. The context is a much bigger one having to interact at times with the main regional economic trend, "benefitting" from the market's opportunities. We would also need to mention that the agricultural profile of the rural areas represents the only solution for the capitalism's failure, being also the only solution to maintain them (Lipton, 1997).

It is well knows that the vulnerability phenomena have a changing behavior (Gifford, 2011), where the social factors are compared with a living body, being crossed by a series of continuous flows (Ianoș, 2000a), therefore in the perspective of such changes, we need to take into consideration the issue of the increase in houses density and also that of the impact this might have on the land itself as there are (Herman, 2009a, 2009b, 2010), in these cases field drainages (Pompeii, 2015) and also the impact of the derived processes.

The problem with the analysis scale ( $\mathrm{Li}$ and Farber, 2016) on the impact over agriculture show that these specific areas can compete with the much more well-developed ones from the Western Europe, which in itself, represents a real challenge, but also a problem for the Eastern regions of Europe, these ones having gaps in each of the analyzed fields. Therefore, our study will aim to present these comparisons at a local level, because the well-developed areas can hold strong impact in the areas already adapted to the national economic environment. Such an approach sustained on a lower scale represents a first step in the settlement of possible unforeseeable effects.

One of the questions one might ask is "how long is the road from rural poverty to rural development? What we can do to make it shorter?" (Chirica and Tesliuc, 1999), questions with an important socio-structural impact, in which the agricultural economy is analysed throughout a decade, which has therefore gone through different stages with a highlight encountered in a country which nowadays has two different units: a military one (N.A.T.O.) and an economic one (The European Union) which establishes a proper environment for development and also for investments, including agricultural ones (Nistor, 2014).

However, a comparison can be made between the highly disadvantaged areas and the ones that are less advantaged, the last ones being part of the first category, besides the aspects surrounding the repercussions of climatic changes, these settlements can be disadvantaged also by the structural deficit aspects (the lack of education, the poor sanitation system, the implementation of inadequate politics, illiteracy etc.) (Lemos et al., 2016).

Agriculture as an economic branch is based on the principle of returning the investments (ROI, Return of Investment) (Yet et al., 2016). This can be affected by the extreme phenomena such as drought (Zhu et al., 2016), which can have a negative impact on the irrigation system, or, on the contrary, it could be affected by heavy rains which can compromise the entire agricultural production (Latocha et al., 2016). These phenomena have an increasing incidence mainly because of the global warming. This having been said, these areas should benefit from a special status, being protected by the political authorities (Berger et al., 2016). The aim of this orientation is to 
create a strong cooperation between main actors, local authorities, local population and investors, therefore creating also different proactive fields in the emergence of such calamities (Kampragou et al., 2011; Sivakumar et al., 2014; Carrao et al., 2016). Such a collaboration is remarkable, however, the political interests and also the bureaucracy make it hard to be implemented.

\section{DATA AND METHODOLOGY}

As for the methodology used in this paper, a series of steps have been followed. The first one was the relativity of basic indicators, based on dividing the indicators and the number of population from 2012, and then with the help of the resulted values, the numbers have been standardized with the following formula: $\frac{V \text { real-Vmin }}{V \max -V \min }$, where: $V_{\text {real }}$ is the value from the list of numbers; $\mathrm{V}_{\min }$ is the minimum; $\mathrm{V}_{\max }$ is the maximum. The standardized values are between 0 and 1. After processing the data, these have been calculated with the aid of the Hull indicator (Ianoș, 1997), the function used being the following: $I_{\text {Hull }}=50+14 *\left(i_{1}+i_{2}+i_{3} \ldots . i_{1}-i_{2}-l_{3} \ldots\right) / \mathrm{No}$. of indicators, where the medium is 50, and in our case, 5 classes have been used in a single perspective. The category comprising the poorly developed agriculture figures contains the values between 48.56 and 49.5 , and it is followed by the category with average values (between 50 and 50.5), and then by the category of the highervalues (between 50.5 and 51) and then last but not least, the category with very high values (between 51 and 52.3).

Therefore, the analysis shapes the image of the agricultural development's degree in the rural areas from Arges County. The values used in this paper are, at the level of 2012, and target the villages 95 villages. The main statistical information come from the online Tempo database, which have been modelled with Excel and also ArcMap. The approach of this topic includes analysis from a scale perspective (Schelling, 2006) aimed to detail the problems encountered in agriculture, which represents such an important field in economy.

\section{CASE STUDY}

Argeș County has all the three large landscape units and also a population of 427.689 (in 2017), in which 51.28\% come from rural areas. The main economic advantages are the geographic location (close to the municipality of Bucharest, to which it is connected via the A1 highway) (figure 1) and the machine building industry, well developed in Mioveni.

The case study has been made at a basic level in Argeș County. The analysis takes into account 95 communes. Also, the analysis contains a physico-geographic delimitation through the introduction of more restrictive rules such as the high average slope of $20 \%$ and an average altitude higher than 700 metres. Based on the conceptual delimitations from this analysis, we have excluded 16 rural administrative units situated in the northern part of the county.

\section{DATA COLLECTION}

For the study under discussion, we have used data from the National Institute of Statistics, statistical yearbooks from Argeș County and also some other documents, analyzing 2012 as a reference year.

\section{METHODS}

This paper analyzes the development level of agriculture in Argeș County (figure 1). Given the fact that the economy is mainly based on agriculture, other social aspects of the area are influenced by agriculture as well. The degree of development in agriculture shows the main disposal of well-developed areas and also their particularities. Moreover, based on the relief features in the other more poorly developed areas, the development of other economic fields or the development of agriculture might emerge (Ianoș, 2000b; Austrhein et al., 2016). In our case, the areas which have not reached the physico-geographic parameters have a small population $(7.79 \%$ of the total population from Argeș County). 
As one can see (figure 2), based on the spatial distribution, four categories of agricultural development have been identified, each of these having one or more indicators concerning agricultural aspects.

The first one is way in which the land is used, represented in its turn by the arable surfaces, by meadows and pastures; by the number of unproductive lands; the degree of fragmentation of agricultural surfaces represented by the number of landlords and the number of agriculture companies; the viability of agricultural companies, the type of agricultural land exploitation, debts and profit; the agricultural surfaces administrated by landlords, areas in concession, on lease, with free title, in rent, or used in other ways. Based on the Hull indicator, 17 indicators have been selected.

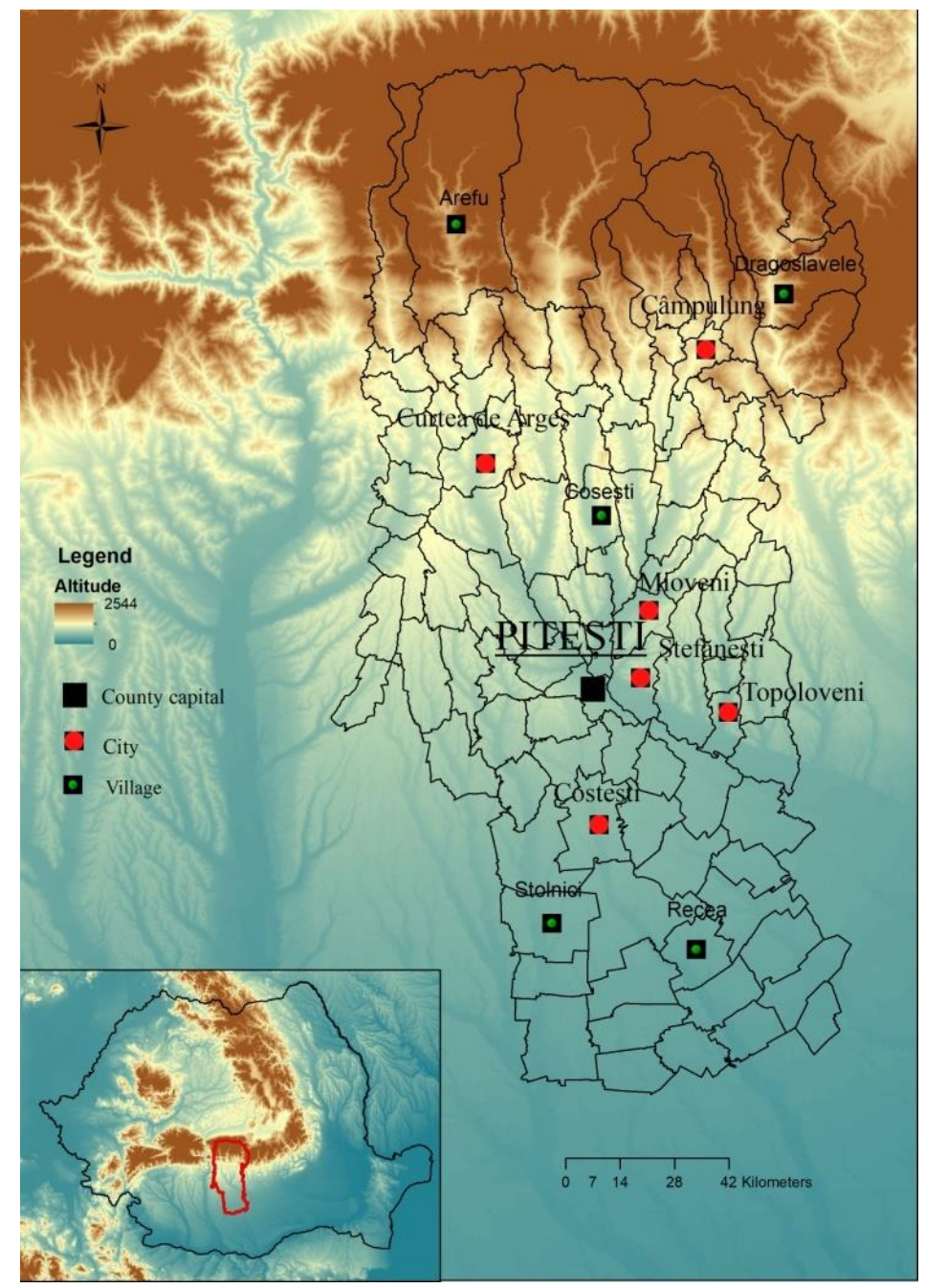

Figure 1. The geographical position of Argeș County has in Romania and in the region

The positive indicators are the vineyards, the orchards, arable lands, the farmed outlands, the leased ones, the ones with a free title, the agricultural companies' profit, the fiscal value, the number of agricultural companies. On the other hand, the negative indicators are the number of landlords, the companies' debts, the agricultural land used in other different ways by their landlords, the degraded land, the meadows and the pastures. 


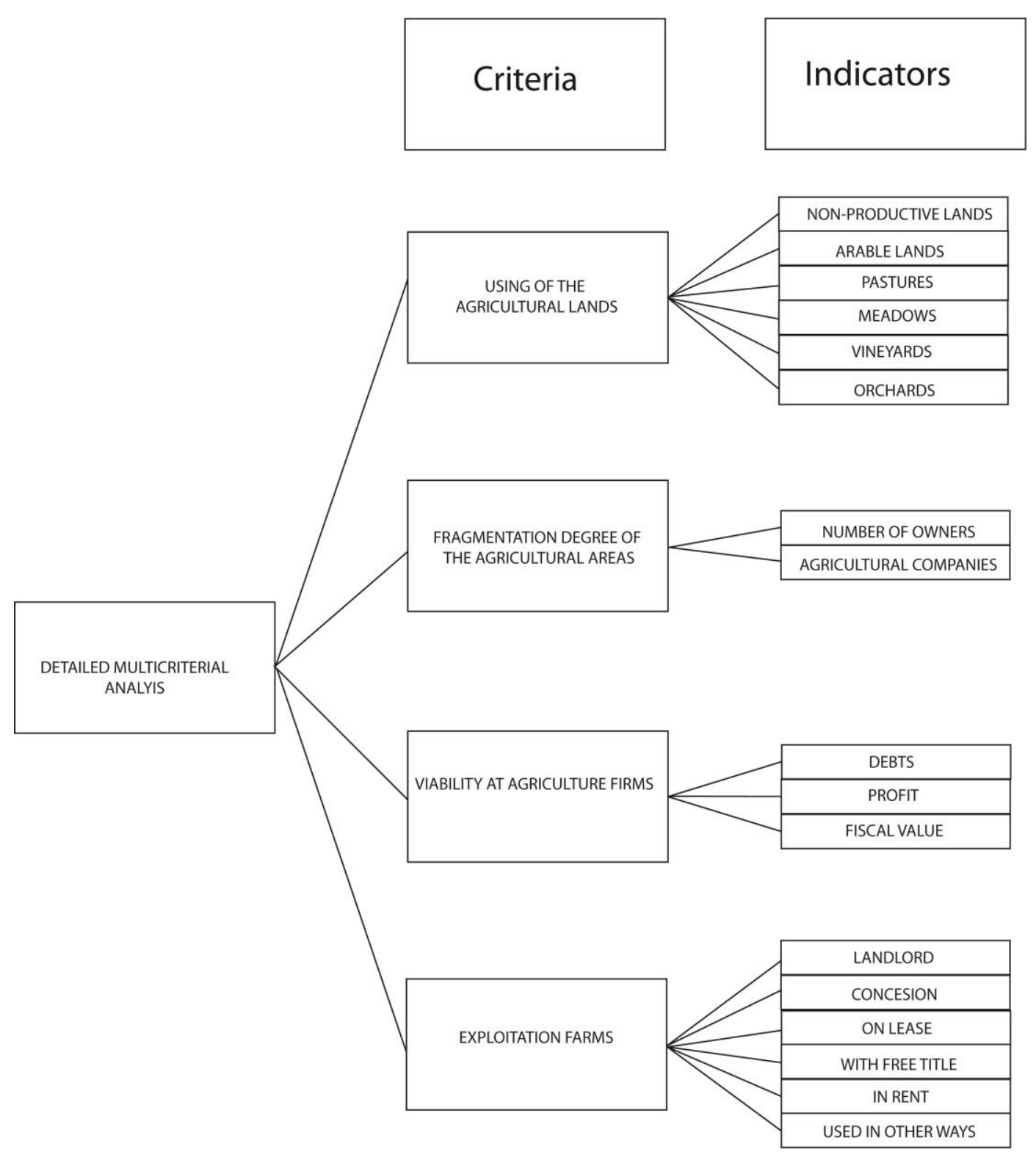

Figure 2. The agricultural development diagram

\section{RESULTS}

The first cartogram (figure 3) shows the value of the Hull indicator, which was calculated based on the rural administrative units. This has happened due to the change of the main values. If the urban settlements value had been included within the relativization and standardization the results and values of the analysis would have been completely different.

The minimum of 48.56 can be found in Călinești, and from the first category, we can find only Merișani, these ones being found in the central part of the county. The low level of 
agricultural development in the two communes is given mostly by the lack of competitiveness in the agricultural field. These are based on the outsourced services in the urban area.

It can be noted that with the elimination of the administrative units such as cities and municipalities, there are lower values for the Hull indicator. Basically, by eliminating them, the issue of agricultural developmentis better outlined.

The next important category is the one with poorly-developed agriculture, containing 39 administrative units. Their share represents $40.6 \%$ from a total of 95 studied administrative units and a total percentage of $42.7 \%$ from the administrative units with a poorly-developed agriculture. The communes with negative indicators are situated in the northern-central part, which sustains the idea that, in such area the agriculture is not an important part of the economy and there are other well developed industries such as tourism or wood exploitation.

On the opposite side, there is another grouping in the southern part, based on the communes with a high degree of development in agriculture. The highest value can be found in Râca (a value of 52.3) and also in Popești, Slobozia, Izvoru, Mozăceni, Stolnici, Buzoiești, Rociu, Budeasa etc. The high degree of agricultural development in the transition economies is given by the economic profile of those administrative units where the economic structure is agrarian, predominantly. The positive values are encountered in the communes in the lowland areas where these ones take advantage from the fertile lands in terms of practicing agriculture and where businessmen have own large surfaces of agricultural land.

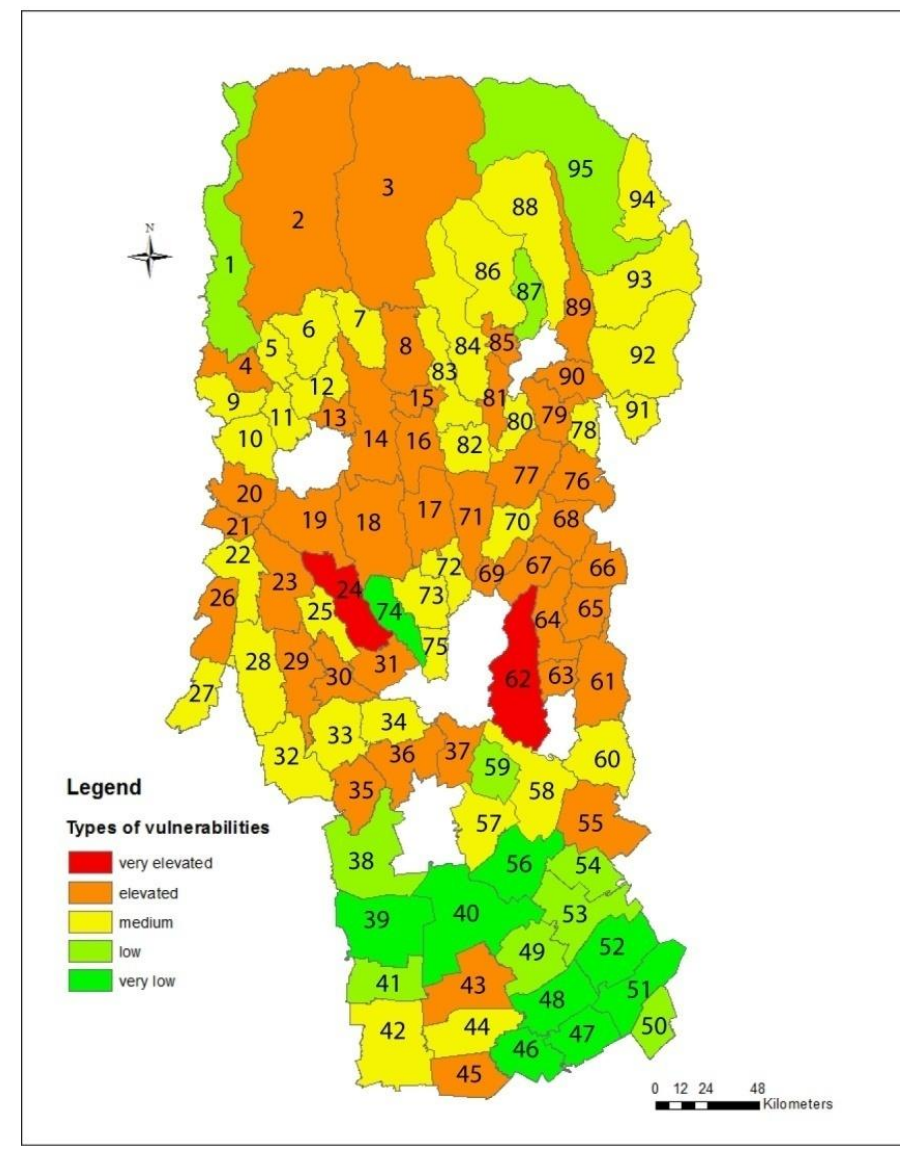

Figure 3. The level of agricultural developement in the rural areas from Argeș County (Source: INSSE, Statistical Yearbooks from Argeș County) 
The settlements in Arges County marked with numbers in figure 3 are: 1 Sălătrucu, 2 Arefu, 3 Nucșoara, 4 Șuici, 5 Cicănești, 6 Corbeni, 7 Brăduleț, 8 Corbi, 9 Cepari, 10 Tigveni, 11 Valea Danului, 12 Albeștii de Argeș, 13 Valea Iașului, 14 Musătești, 15 Domnești, 16 Pietroșani, 17 Cosești, 18 Mălureni, 19 Băiculești, 20 Ciofringeni, 21 Poienarii de Argeș, 22 Morărești, 23 Cotmeana, 24 Merișani, 25 Drăganu, 26 Cuca, 27 Ciomăgești, 28 Uda, 29 Cocu, 30 Babana, 31 Bascov, 32 Vedea, 33 Poiana Lacului, 34 Moșoaia, 35 Sapata, 36 Albota, 37 Bradu, 38 Lunca Corbului, 39 Stolnici, 40 Buzoiești, 41 Hârsești, 42 Bârla, 43 Ungheni, 44 Căldăraru, 45 Miroși, 46 Râca, 47 Popești, 48 Izvoru, 49 Recea, 50 Ștefan cel Mare, 51 Slobozia, 52 Mozăceni, 53 Negrași, 54 Teiu, 55 Rătești, 56 Rociu, 57 Suseni, 58 Cățeasca, 59 Oarja, 60 Leordeni, 61 Bogaţi, 62 Călinești, 63 Priboieni, 64 Beleți Negrești, 65 Dobrești, 66 Boțești, 67 Davidești, 68 Vulturești, 69 Țițești, 70 Stâlpeni, 71 Bălilești, 72 Dârmănești, 73 Micești, 74 Budeasa, 75 Mărăcineni, 76 Vulturești, 77 Mihești, 78 Boteni, 79 Poienarii de Mușcel, 80 Schitu Golești, 81 Godeni, 82 Vlădești, 83 Aninoasa, 84 Berevoiești, 85 Bughea de Jos, 86 Albeștii de Mușcel, 87 Bughea de Sus, 88 Lerești, 89 Valea Mare Pravăț, 90 Mioare, 91 Cetățeni, 92 Stoenești, 93 Dragoslavele, 94 Dâmbovicioara și 95 Rucăr.

The physical issues encountered in the mountain areas in terms of agricultural development have led to the implementation of special actions within the European Union (Renwick et al., 2013; Hinojosa et al., 2016). Given the fact that Romania is one of the poorest countries in the EU (the second to last place in the EU in terms of the GDP/per capita in 2015, according to the World Bank), having a lower experience compared with other states ( $1^{\text {st }}$ of January 2007), and also having profoundly disadvantaged rural areas, only the areas with a favorable altitude for agricultural development have been included. An eloquent example in determining the agricultural areas is represented by the French Alps, which have "a minimum average altitude of $700 \mathrm{~m}$ or slopes larger than $20 \%$ (figure 4 and figure 5). Alternatively, the requirement is "a minimum average altitude of $500 \mathrm{~m}$ and an average slope of 15\%" (Hinojosa et al., 2016: 117-118). Based on these parameters, we have determined which are the communes that do not have the specific physical characteristics to the plant cultivation. The established level was that of the average slope at the commune level of over 20 degrees and an average altitude of less than 700 meters.

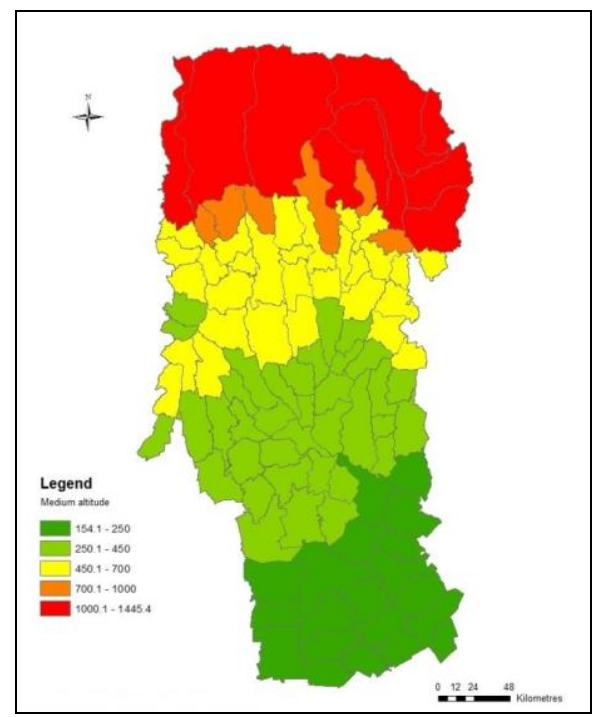

Figure 4. The average analysis of the average altitudes in Argeș County

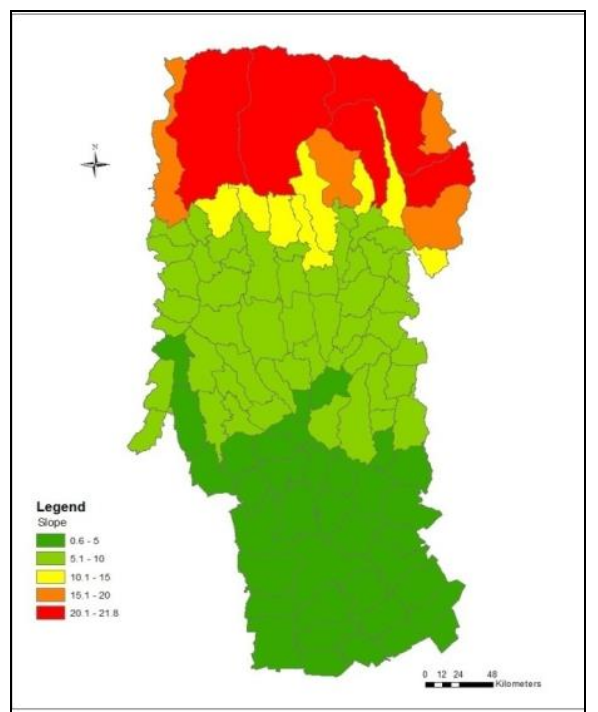

Figure 5. The average analysis of the slopes in Argeș County 
As a result of the conceptual delimitation, 16 rural administrative units appeared in the analysis. They are situated in the northern part of Argeş County.

The portraying of low agricultural development due to the urban environment in the central part of Arges County creates a major problem at the level of crop cultivation.

Even though the county has 3 different landforms, the Carpathian Mountains (in the north), the Piedmont Plateau (in the centre), the Romanian Plain (in the south), we cannot consider it a typically agrarian county. It is assumed that the administrative units located in the central part of the county overlap with landforms such as plains. Regarding the relative values used in the obtaining the Hull indicator, it's simple to observe the similarities between their divisions and the communes' grouping by the number of inhabitants. The localities from the southern part of Arges have an average population much more elevated and a much more extended agricultural surface. On the other hand, the communes in the center of the county have a smaller average population (except the ones closer to cities/towns) and a smaller agricultural surface. Therefore, we can consider that the disposal of agricultural development in this analysis is not related with the fragmentation but more with the economic character of the administrative units (the manufacturing industry).

\section{CONCLUSIONS}

Among the ways in which the living standard could be increased in some areas, there is the awareness of the population regarding their capacity to be organized in associations. In this respect, there needs to be a longer process treating a sensitive subject for the Romanian mentality, with thinking reminiscences coming from the interwar period (Ianoş and Braghină, 2006). At the same time, the rhythm in which this new information is assimilated and also the implementation of new technologies confirm that Romania is a dynamic competitor and an important hub for the regional agriculture, and they also show the important relationships our country has in the Middle East and also in the Western Europe.

The fertile lands in Romania (Popa et al., 2016) and the small areas of polluted soil (Juravle et al., 2016) offer credibility to those mentioned earlier in this paper, having the perfect development framework in this direction, therefore they can be the basis for a long-term development where the alternatives of support through agriculture are built on the new trends, such as agro-tourism (Kazeminia et al., 2016) or ecotourism (Ciolac et al., 2015; Dincă et al., 2012) much more sustainable from a financial point of view.

There are different ways in which these localities can benefit from development and from a limitation of these economic development, and we can here mention the role of associative form of administrative units such as G.A.L.s (Local Action Groups). These are manifested through the encouragement of entrepreneurship, of associating institutions and private companies so as to access European funds for a specific economic sector. Therefore, the association initiatives which might determine the development of this area are encouraged through the community and national legislation (governmental decision 725/2010, 244/2008, 74/2009 or the Board Rules 1975/2006. $1698 / 2005$ etc.). In our opinion, the GALs have not been effective due to lack of information on their capacity to push the agriculture development in rural areas. Most of the times, they have many localities included, therefore the decision factor represents an impediment. Another issue is that not all the GALs respect the law, including and working together with a small town.

It is possible that some of the elevated values from the Hull indicator are registered in the southern part of the county because those areas depend on the agricultural economy. The spectrum of this analysis does not allow a comparison with the much more developed areas from the agricultural infrastructure point of view. On the other hand, such problems could not be so visible statistically speaking.

Therefore, this particular analysis can be a foundation for the development of future projects in the agricultural field, through the local institutions and especially through local public figures. These limit the phenomenon of vulnerability in this economic sector, through awareness of problems and the implementation of related measures that could limit the economic development, 
too. Also, the prevention methods do not necessarily forecast the development of agriculture in all territorial units, because the economic structure needs to be varied and it would be essential to have inside a high value for the market products.

Acknowledgement: This work was supported by a grant of the Romanian National Authority for Scientific Research and Innovation, CNCS - UEFISCDI, project number PNII-RUTE-2014-4-1481 and by the project UB-2008 "Trans-scale analysis of the territorial impact of current climate change and globalization".

\section{Author contribution}

All the authors had equal contribution.

\section{REFERENCES}

Berger, T., Schreinemachers P., \& Woelcke J. (2006). Multi-agent simulation for the targeting of development policies in less-favored areas, Agricultural Systems, 88: 28-43.

Bose, P.S. (2015). Vulnerabilities and displacements:adaption and migration to climate change as a new development mantra. Department of Geography, University of Vermont, Burlington, ed Royal Geographical Society: 1-8.

Bunnell, T. G., \& Coe, N. M. (2001). Spaces and scales of innovation, Progress in Human Geography, 25 (4), $569-589$.

Carrao, H., Naumann, G., \& Barbosa, P. (2016). Mapping global patterns of drought risk: An empirical framework based on sub-national estimates of hazard, exposure and vulnerability. Global Environmental Change, 39: 108-124.

Chirica, C., \& Teșliuc, E. D. (coord) (1999). From Rural Poverty to Rural Development. Ed.World Bank: 1-142.

Ciolac, R., Isac, E., Tonea, E., Hurmuzache, T., Sîrbu, C., \& Marin, S. (2015). Agrotourism-Traditional knowledge and rural biotechnology. Journal of Biotechnology, 208: 62.

Dincă I., Herman G.V., \& Sztankovics G. (2012). Descoperire prin ecoturism si prin turism rural în Comuna Cetariu [Discovery through ecotourism and rural tourism in Cetariu], Editura Universităţii din Oradea, ISBN 978-606-100724-0, Oradea.

Filimon, C., Filimon, L., \& Nemeș, V. (2014). Agriculture between identity and vulnerability. The case of Țara Beiușului (Beiuș land). Analele Universității din Oradea, Seria Geografie, 24 (1):23-31.

Gifford, R. (2011). The dragons of inaction: psychological barriers that limit climate change mitigation and adaptation. American Psychologist, 66 (4): 290-302.

Herman, G.V. (2009a). Omul şi modificările antropice din Câmpia Someşului [The man and anthropogenic changes in Somes Plain], Editura Universităţii din Oradea, 227 pag., ISBN 978-973-759-981-0, Oradea.

Herman, G.V. (2009b). Ways of anthropic intervention in the Someşului Plain. Analele Universităţii din Oradea, Seria Geografie, 20(1): 120-126.

Herman, G.V. (2010). Structure and share of agricultural lands, key indicators in quantifying the anthropogenic impact in the Somes Plain. Analele Universităţii din Oradea Fascicula Construcţii şi Instalaţii Hidroedilitare, 13(2): 153-159.

Hinojosa, L., Napoleone C., Moulery M., \& Lambin E.F. (2016). The "montain effect" in the abandonment of grassslands: Insights from the Franch Southern Alps. Agriculture, Ecosystems \& Environment, Vol. 221: 115-124.

Ianoș, I. (1997). Individualizarea și analiza disparităților intraregionale. Aplicație la județul Alba, Comunicări de Geografie. Bucharest University Publishing House, Vol. I: 1-105.

Ianoș, I. (2000a). Sisteme teritoriale: o abordare geografică. Ed. Tehnica, 1-197.

Ianoș, I. (2000b). The impact of transition on the mountain agriculture of Alba judet (Apuseni mountains). Analele Universității din București, Seria Geografie, an XLVIII, 49-62.

Ianoș, I., \& Braghină, C. (2006). The Structural Dynamics of the Romanian Economy furing the Transition Period. Bul. $S G R$, serie nouă, TOM XII (XXCII), 69-84.

Juravle, D.T., Secu C.V., Breabăn, I. G., Lesenciuc, D.C., Kasper, H.U., \& Bobric, E.D. (2016). Pedo-geochemical differences between young soils: regosols and spolictechnosols in northern part of eastern carpathians (Romania). Journal of Environmental Protection and Ecology, No. 2: 566-575.

Kampragou, E., Apostolaky, S., Manoli, E., Froebrich, J., \& Assimacopoulos, D. (2011). Towards the harmonization of water-related policies for managing drought risks across the $\{$ EU \}. Environ. Sci. Policy 14: 815-824.

Kazeminia, A., Hultman, M., \& Mostaghel, R. (2016). Why pay more for sustainable services? The case of ecotourism. Journal of Business Research, Volume 69, Issue 11: 4992-4997.

Latocha, A., Szymanowsky, M., Jeziorska, J., Stec, M., \& Roszczewska, M. (2016). Effects of land abandonment and climate change on soil erosion-An example from depopulated agricultural lands in the Sudetes Mts., SW Poland. Catena, Volume 145: 128-141.

Lemos, M.C., Lo, Y.J., Nelson, D.R., Eakin, H., \& Bedran-Martins, A.M. (2016). Linking development to climate adaption: Leveraging generic and specific capacities to reduce vulnerability to drought in NE Brazil. Ed. Global Environmental Change, 170-179. 
Li, X., \& Farber, S. (2016). Spatial representation in the social interaction potential metric: an analysis of scale and parameter sensivity. Journal of Geographcal Systems, Volume 18, Issue 4: 331-357.

Lipton, M. (1977). Why poor people stay poor: Urban bias in world development. Cambridge, MA: Harvard University Press, Volume 84 (3), 1-467.

Nistor, P. (2014). FDI and the legal framework in Romania. STUDIA UNIVERSITATIS PETRU MAIOR, SERIES OECONOMICA, Volume 1: 88-104.

Pompeii, B. (2005). Reverse osmosis on a small barrier island:transformations of water, landscape, and vulnerability on Ocracoke Island, NC, USA. Ed. GeoJournal: 457-473.

Popa, M., Lațo, A., Corcheș, M., Radulov, I., Berbecea, A., Crista, F., Niță, L., Lațo, K.I., \& Popa, D. (2016). Quality of some soils from the west region of Romania, AgroLife Scientific Journal, Volume 5, No. 1: 174-177.

Renwick, A., Jonsson, T., Verburg, P.H., Revoredo-Giha, C., Britz, W., Gocht, A., \& McCracken, D. (2013). Policcy reform and agricultural land abandonment in the EU. Land Use Policy, 30: 446-457.

Schelling, T.C. (2006). Micromotives and Macrobehavior, Copyright 2006, 1978 by W.W. Norton \& Company. Inc, 1-263.

Sivakumar, M.V., Stefanski, R., Bazza, M., Zelaya, S., Wilhite, D., \& Magalhaes, A.R. (2014). High level meeting on national drought policy: Summary and major outcomes. Weather Clim. Extremes 3: 126-132.

Yet, B., Constantinou, A., Fenton, N., Neil, M., Luedeling, E., \& Shepherd, K. (2016). A Bayesian network framework for project cost, benefit and risk analysis with an agricultural development case study. Expert Systems with Applications, Volume 60: 141-155.

Zhu, Y., Wang, W., Singh, V. P., \& Liu, Y. (2016). Combined use of meteorological drought indices at multi-time scales www.insse.ro. for improving hydrological drought detection. Science of The Total Environment, Volume 571: 1058-1068.

Submitted:

September 29, 2018
Revised:

March 03, 2019
Accepted and published online April 09, 2019 